\title{
Innlagnir unglinga á Vog helmingi færri nú en árið 2002
}

\section{Pórarinn Tyrfingsson}

forstjóri á Sjúkrahúsinu Vogi

thorarinn@saa.is

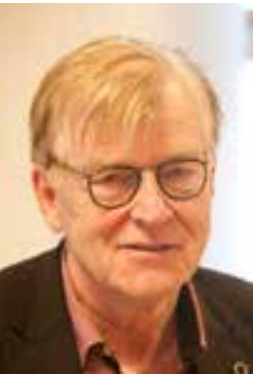

Árið 1977, pegar SÁÁ var stofnað, var unglingadrykkja vel pekkt vandamál á Íslandi og unglingar á aldrinum 15-19 ára byrjuðu snemma að koma par til meðferðar. Á 9. áratugnum fjölgaði unglingum í meðferð jafnt og pétt og kannabisneysla varð algengari meðal peirra. Á árunum 1995-2000 jukust innritanir áfengis- og vímuefnasjúklinga á aldrinum 15-19 ára á Vog skyndilega úr rúmlega 100 á ári í rúmlega 300 árlega á pessum aldri. Nýgengi ungu sjúklinganna varð mest árið 2002 og fór pá í rúmlega 800 á hverja 100.000 íbúa á aldrinum 15-19 ára. Síðan hefur dregið stöðugt úr nýgengi innlagna peirra sem eru yngri en 20 ára og árið 2015 var pað komið niður í tæp 300 á sama mælikvarða.

Sjúklingahópurinn sem kemur til afeitrunar hjá SÁÁ breytist ár frá ári. Á upphafsárunum settu túradrykkjumenn mestan svip á hópinn og hlutur kvenna fór hratt vaxandi, hlutfall peirra fór úr $20 \%$ í rúm 30\%. Um 1980 urðu kannabissjúklingarnir á aldrinum 20-30 ára meira áberandi í hópnum. Stóra breytingin kom svo 1983 pegar ungu kannabissjúklingarnir fóru að nota ólöglegt amfetamín í vaxandi mæli og sjúklingar sem notuðu vímuefni í æð sáust í fyrsta skipti í Reykjavík.

Upp úr 1995 fór neysla vímuefna hratt vaxandi á Íslandi og hélst mikil fram yfir aldamót. Kókaín kom til Reykjavíkur 1999 og vímuefnasjúklingar sem sprautað höfðu amfetamíni í æð sóttu í vaxandi mæli í morfín sem peir leystu upp úr forðatöflum ætluðum verkjasjúklingum. Ástandið fór hratt versnandi en átakanlegast var pó að áður ópekktur fjöldi ungmenna 19 ára og yngri rataði í vímuefnavanda. Unglingar höfðu alla tíð verið hluti af sjúklingahópnum hjá SÁÁ en svo brá við rétt fyrir síðustu aldamót að fjöldi ungu einstaklinganna sem lagðist inn á Sjúkrahúsið Vog ríflega tvöfaldaðist árlega. Innritanirnar hjá pessum aldurshópi fóru vel yfir 300 á hverju ári og fjöldinn fór úr tæplega 100 í rúmlega 200 árlega. Ljóst var að í óefni stefndi.

SÁÁ brást við pessum vanda með pví að byggja við Sjúkrahúsið Vog 11 rúma deild fyrir unglinga sem voru 19 ára og yngri og stórauka göngudeildarpjónustu. Unglingameðferðin var endurskipulögð og boðið upp á göngudeildarpjónustu fyrir unglingana og foreldra peirra, bæði fyrir og eftir Vogsdvölina. Síðan hafa unglingar ekki purft að bíða eftir leguplássi á Vogi.

Á síðustu 20 árum hefur umfang pjónustunnar fyrir unglinga verið mikið. Á árunum 1996-2015 leituðu 2853 einstaklingar (kvenhlutfall 37,7\%) sem voru 19 ára eða yngri sér meðferðar í fyrsta sinn. Á sama árabili voru innritanir fyrir sama aldurshóp 6340. Рað vímuefni sem gerir unglingana helst félagslega óvirka er kannabis en peim stafaði einnig hætta af amfetamíni, e-pillu, morfíni og vímuefnaneyslu í æð.

Árangur í slíkri meðferð næst fyrst og fremst með mikilli vinnu, prautseigju, fjármagni og góðum húsakosti. Skyndilausnir eru ekki til pó peim sé oft lofað.

Meðferðin á Vogi bjargar mannslífum pví að í ljós hefur komið að prátt fyrir ýmiskonar meðferðarinngrip er pessi ungi sjúklingahópur í mun meiri hættu á að deyja ótímabært en jafnaldrar peirra. Á árunum 2001-2005 var áhættan 11 sinnum meiri (relative risk 11,4) en 7 sinnum meiri á árabilinu 2005-2010 fyrir pá sem voru 15-19 ára. Sjúkrahúsið Vogur býður pessum hópi upp á flýti- og skyndiinnlagnir par sem markmiðið er að koma jafnvægi á hættuástand vegna neyslunnar og í framhaldi að aðstoða foreldra og forráðamenn unglingsins við að skapa félagslega umgjörð og aðhald sem dregur úr alvarleika ástandsins.

Áhugahvöt unglinga til að breyta vímuefnaneyslunni er oft lítil framan af. Markmiðið er pá að fleyta hópnum í gegnum slysa- og sýkingahættur par til samstarfsvilji skapast til markvissrar meðferðar. 678 úr pessum hóp hafa sprautað vímuefnum í æð og 475 byrjuðu á pví fyrir tvítugt. 237 hafa fengið lifrarbólgu C og par af 92 fyrir tvítugt. Í byrjun árs 2016 var ljóst að 168 pessara einstaklinga purfa lyfjameðferð og 49 hafa pegar hafið slíka meðferð hjá SÁÁ og Landspítala pegar petta er skrifað.

Meðferðin á Sjúkrahúsinu Vogi er oft upphaf að auknum lífsgæðum og varanlegu bindindi. Pegar sjúklingar undir tvítugu koma til meðferðar í fyrsta sinn er ekki hægt að vænta pess að nauðsynlegur samstarfsvilji skapist eins oft strax og hjá peim fullorðnu. Margir hinna ungu eru líka hálfpvingaðir til meðferðar í fyrstu innlögn. Prátt fyrir petta næst oft góður árangur í fyrstu meðferð og margur unglingurinn kemur fljótt til endurinnlagnar með breytt hugarfar. 1487 einstaklingar af umræddum 2853 unglingum, eða 52\%, hafa einungis komið á Vog einu sinni og 83\% hafa verið par prisvar sinnum eða sjaldnar frá 1996-2015.

Ekkert heilbrigðisvandamál er jafn algengt og hættulegt fyrir unglinga og notkun vímuefna. Раð er pví fagnaðarefni að áfengis- og vímuefnavarnir Íslendinga hafi skilað svo góðum árangri að innlögnum vegna áfengis- og vímuefnasjúkdómsins hjá 15-19 ára ungmennum hafi fækkað um rúmlega helming frá árinu 2002.

\footnotetext{
Admissions of adolescents at Vogur have fallen by over $50 \%$ since 2002

Pórarinn Tyrfingsson MD Head Physician at Vogur
} 